\title{
ANALISIS KESALAHAN SISWA KELAS VII DALAM MENYELESAIAN SOAL CERITA PADA MATERI HIMPUNAN
}

\author{
Munawaroh $^{1}$, Eka Liani Resta ${ }^{2}$ \\ Pasca Sarjana Pendidikan Matematika Universitas Negeri Riau ${ }^{1.2}$ \\ Email: munawaroh6792@grad.unri.ac.id \\ Email: ekalianaresta6592@grad.unri.ac.id
}

\begin{abstract}
This research is motivated by the high errors of students in solving story problems. The purpose of this research is to find out the types of student mistakes in solving story problems in Class VII based on the Polya step consisting of four steps, understanding the problem, the plan, implementing the plan, and check bach answers. This type of research is descriptive qualitative research. The data collection method used is test and documentation. The subject of this research is the students of 1st mempura junior high school. The results showed that there were four errors in completing the set material story questions, misunderstanding the problem of $5.33 \%$, planning errors of $32.66 \%$, errors in implementing the plan of 40\%, and errors in checking the answers of $22 \%$. In this research the biggerst mastake was made in the step of implementing the plan. This research could be a reference for future research.
\end{abstract}

Keyword : Student error, story problem, set

\begin{abstract}
Abstrak
Penelitian ini dilatarbelakangi oleh tingginya kesalahan melaksanakan rencana siswa dalam menyelesaikan soal cerita.Tujuan penelitian ini adalah untuk mengetahui jenis kesalahan siswa dalam menyelesaikan soal cerita pada materi himpunan Kelas VII berdasarkan langkah Polya dengan empat langkah, yaitu kesalahan memahami soal, kesalahan menyusun rencana, kesalahan melaksanakan rencana, dan kesalahan memeriksa kembali solusi yang diperoleh. Jenis penelitian ini adalah penelitian kualitatif deskriptif. Metode pengumpulan data yang digunakan adalah tes dan dokumentasi. Subjek penelitian adalah siswa kelas VII.4 SMP Negeri 1 Mempura berjumlah 24 siswa. Hasil penelitian menunjukan bahwa terdapat empat kesalahan dalam menyelesaikan soal cerita materi himpunan, yaitu kesalahan memahami masalah sebesar 5,33\%, kesalahan menyusun rencana sebesar 32,66\%, kesalahan melaksanakan rencana sebesar $40 \%$, dan kesalahan mengecek kembali jawaban sebesar $22 \%$. Pada penelitian ini kesalahan terbesar dilakukan pada langkah melaksanakan rencana. Penelitian ini dapat menjadi kajian referensi penelitian selanjutnya.
\end{abstract}

Kata Kunci: Kesalahan siswa, soal cerita, himpunan

CPendidikan Matematika UIN Raden Fatah Palembang 


\section{PENDAHULUAN}

Materi himpunan adalah salah satu materi penting yang diajarkan kepada siswa SMP dan dapat digunakan untuk menyelesaikan masalah dalam kehidupan sehari-hari dimana siswa dituntut untuk dapat memahami dan memecahkan soal berbentuk cerita (M. Cholik A, 2014). Materi himpunan merupakan salah satu konsep dasar yang harus dikuasai siswa guna mempermudah siswa dalam mempelajari materi matematika yang lain terutama terkait tentang pemecahan soal-soal berbentuk cerita. Oleh karena itu, materi himpunan menjadi penting untuk dikuasai oleh siswa kelas VII di tingkat sekolah menengah pertama. Dengan menguasai materi himpunan, khususnya soal yang berbentuk cerita, maka materi matematika lainnya akan lebih mudah untuk dipahami, khususnya pada soal yang berbetuk cerita.

Soal cerita (verbal/ word problems) merupakan salah satu bentuk soal atau pertanyaan yang menyajikan permasalahan yang terkait dengan kehidupan sehari-hari dalam bentuk cerita. Soal bentuk cerita biasanya memuat pertanyaan yang menuntut pemikiran dan langkah-langkah penyelesaian secara sistematis, sebagaimana tertulis dalam National Council of Teacher of Mathematics (NCTM) (2010: 1), "some story problems are not problematic enough for students and hence should only be considered as exercise for students to perform." Suatu pertanyaan atau soal yang diajukan kepada siswa merupakan masalah baginya jika pertanyaan atau soal itu tidak segera dapat diselesaikan oleh siswa dengan prosedur rutin namun memberikan rangsangan dan tantangan untuk dijawab (Rochmad, 2011: 2).

Penelitian dari Muhammad khadali Sulis (2018) tentang kesalahan siswa dalam menyelesaian soal cerita pada materi PLSV menunjukkan kesalahan memahami masalah sebesar 16,04\%, kesalahan menyusun rencana sebesar 25,94\%, kesalahan melaksanakan rencana sebesar 36,32\%, dan kesalahan mengecek kembali 21,69\%. Hasil ini menunjukkan kesalahan siswa terbesar pada langkah melaksanakan rencana..

Hasil analisis kesalahan dalam menyelesaian soal cerita SPLDV berdasarkan langkah polya yang merupakan penelitian Shofia Hidayat (2016) disimpulkan bahwa analisis menunjukan besar kesalahan memahami soal 5\%, kesalahan menyusun rencana $21,50 \%$, kesalahan melaksanakan rencana $28,88 \%$ dan kesalahan memeriksa solusi kembali $18,00 \%$. Hasil ini menunjukkan bahwa kesalahan yang banyak dilakukan siswa pada langkah melaksanakan rencana. 
Kesalahan yang dilakukan siswa ketika mengerjakan soal adalah hal biasa dan wajar yang dilakukan oleh siswa. Kesalahan juga dapat mengukur sejauh mana pemahaman siswa pada materi tersebut yang guru ajarkan. Dari kesalahan-kesalahan yang dilakukan oleh siswa tersebut akan berakibat pada hasil belajar yang diperoleh siswa. Agar kesalahan tersebut dapat dikurangi dan dapat meningkatkan hasil belajar maka perlu diadakannya analisis kesalahan. Wijaya \& Masriyah (2013) dalam Ronald Manibuy dkk, menyatakan bahwa letak kesalahan didefinisikan sebagai bagian dari penyelesaian soal yang terjadi penyimpangan dalam mengerjakan soal. Adapun letak kesalahan yaitu: (a) kesalahan dalam memahami bentuk dan maksud soal, (b) kesalahan membuat model matematika, (c) kesalahan dalam menyelesaikan model matematika, dan (d) kesalahan menulis jawaban akhir soal.

Muhammad Khadani Sulis (2017) memaparkan bahwa ada empat langkah yang dapat dilakukan agar siswa lebih terarah dalam menyelesaikan pemecahan masalah dalam pelajaran matematika, yaitu understanding the problem, devising plan, carrying out the plan, dan looking back yang diartikan sebagai memahami masalah, membuat perencanaan, melaksanakan rencana, dan melihat kembali hasil yang diperoleh.

\section{METODE PENELITIAN}

Jenis penelitian ini merupakan penelitian deskriptif kualitatif. Metode yang digunakan dalam penelitian ini adalah metode tes dan dokumentasi hasil jawaban siswa sebagai contoh kesalahan yang dilakukan siswa dengan menggunakan langkah-langkah polya. Siswa diberikan soal sebanyak 5 soal untuk menguji berapa besar tingkat kesalahan dalam menyelesaikan soal cerita dengan 4 langkah polya, yaitu memahami masalah, menyusun rencana penyelesaian, melaksanakan rencana dan mengecek kembali jawaban. Subjek penelitian ini adalah siswa kelas VII.4 SMP Negeri 1 Mempura sebanyak 24 siswa. Penyusunan data menggunakan tes dan dokumentasi.. Hasil test digunakan sebagai pedoman bagi peneliti untuk mengetahui jenis kesalahan yang dilakukan siswa serta dokumentasi hasil jawaban siswa. Teknis analisis data meliputi, Menyusun data, reduksi data, dan penarikan kesimpulan.

\section{HASIL DAN PEMBAHASAN}

Berdasarkan hasil tes yang diberikan kepada siswa kelas VII.4 SMP Negeri Mempura dan dokumentasi hasil jawaban siswa diperoleh data bahwa jumlah siswa yang 
melakukan kesalahan dalam menyelesaikan soal cerita dengan indikator memahami masalah, kesalahan menyusun rencana, kesalahan melaksanakan rencana dan kesalahan mengecek kembali dapat dilihat pada tabel 1

Tabel 1. Jumlah Kesalahan Siswa Pada Setiap Jenis Kesalahan

\begin{tabular}{lcccccc}
\hline \multicolumn{1}{c}{ Kesalahan } & \multicolumn{9}{c}{ Nomor soal } & Total \\
\cline { 2 - 6 } & 1 & 2 & 3 & 4 & 5 & \\
\hline Pemahaman Masalah & 2 & 1 & 2 & 2 & 1 & 8 \\
Menyusun rencana & 5 & 5 & 10 & 15 & 14 & 49 \\
Melaksanakan rencana & 9 & 16 & 15 & 9 & 11 & 60 \\
Pengecekan Jawaban & 10 & 15 & 4 & 3 & 1 & 33 \\
Total & 31 & 34 & 33 & 26 & 26 & 150 \\
\hline
\end{tabular}

Peneliti melakukan pengolahan data untuk menghitung persentase pada tabel 1 setiap jenis kesalahan. Sehingga didapatkan deskripsi persentase setiap jenis kesalahan yang disajikan pada grafik 1 berikut.

Grafik 1. Deskripsi Persentase Setiap Jenis Kesalahan

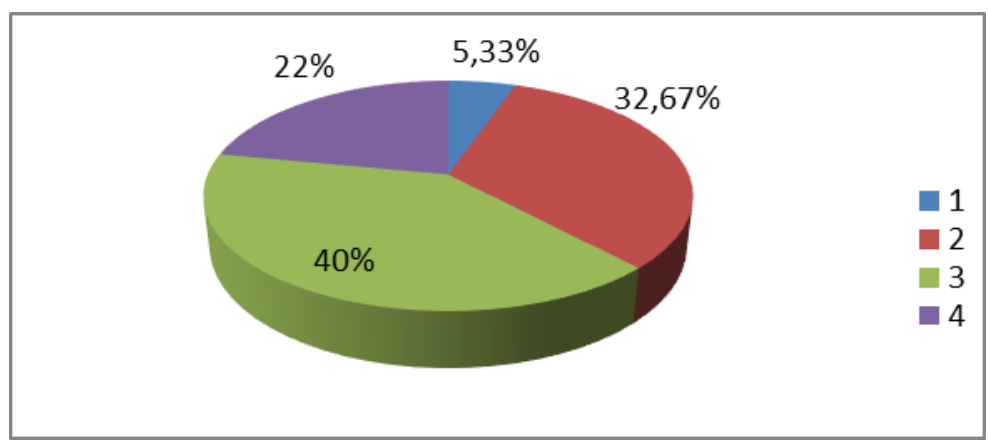

Keterangan :

$1=$ Pemahaman masalah

$2=$ Menyusun rencaana

3 = Melaksanakan Rencaana

$4=$ Mengecek kembali jawaban

Berdasarkan hasil analisa dari dokumentasi hasil jawaban siswa yang telah dilakukan yaitu dari hasil tes siswa dalam mengerjakan soal cerita, akan dideskripsikan jenis-jenis kesalahan yang dilakukan oleh siswa dalam menyelesaikan soal cerita materi himpunan didukung oleh contoh dokumentasi hasil jawaban siswa. Jenis kesalahan yang dilakukan oleh siswa dalam menyelesaikan soal cerita materi himpunan. 
a. Kesalahan Memahami Masalah

Pada penelitian ini siswa yang termasuk dalam kesalahan memahami masalah sebesar 5,33\%. Contoh dokumentasi jawaban kesalahan yang dilakukan oleh siswa pada tingkatan pemahaman dapat dilihat pada gambar 1, berikut:

Dalam suatu kelas terdapat 25 siswa, mereka memilih dua jenis olahraga yang digemari. Ternyata 20 siswa suka gemar bermain sepak bola,15 siswa suka gemar bermain bulu tangkis dan 3 siswa tidak menggemari kedua olahraga tersebut. Dari keterangan tentukan banyaknya siswa yang suka gemar bermain sepak Bola dan Bulu Tangkis?

Jawaban Siswa:

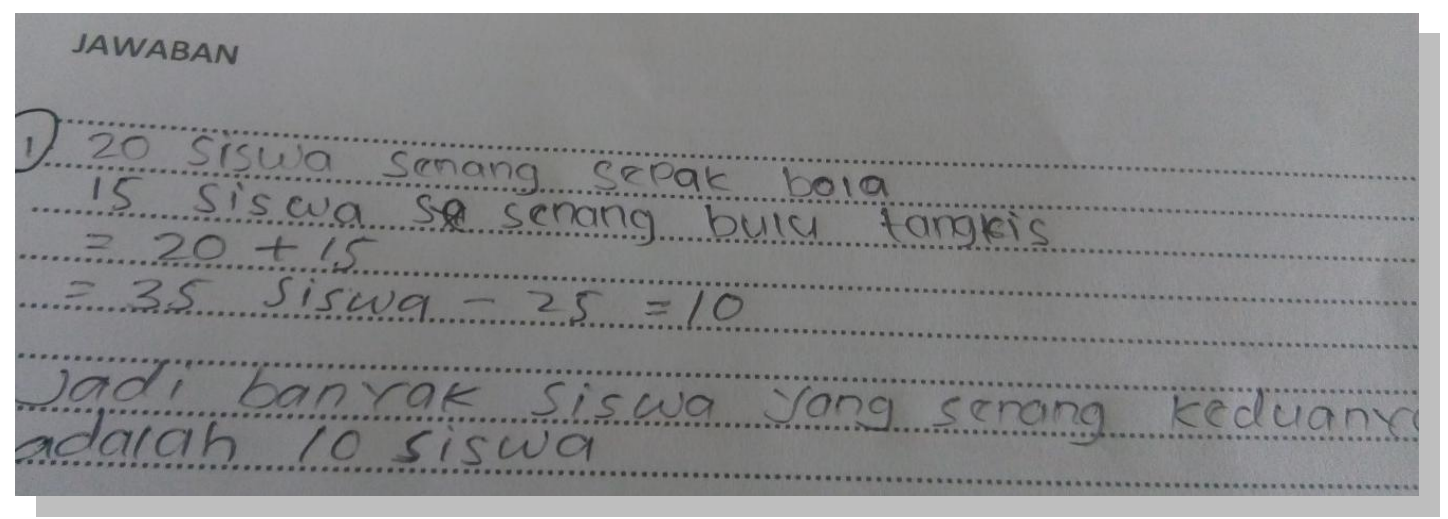

Gambar. 1 Pekerjaan S-8

Gambar.1 menunjukkan kesalahan siswa pada subjek S-8 berdasarkan kesalahan pemahaman masalah. Pekerjaan S-8 menunjukkan bahwa siswa melakukan kesalahan tidak menuliskan Kembali informasi yang disajikan atau tidak dapat mengidentifikasi masalah nyata kedalam kalimat matematika (model matematika). Subjek S-8 menunjukkan kurang memahami apa yang ditanyakan dari soal. Hal tersebut mengakibatkan siswa kesulitan pada langkah pengerjaan selanjutnya.Hal ini sejalan dengan peneltian yang dilakukan oleh Shofia Hidayat (2016) kesalahan yang paling sedikit dilakukan siswa yaitu memahami soal sebesar 5\% dan. Contoh kesalahan pemahaman masalah lainnya pada soal no. 4 sebagai berikut;

Pada acara pendataan terhadap minuman yang disukai siswa kelas 7.4 diperoleh data, terdapat 20 orang suka minum Susu dan 15 orang suka minum Teh. Bila 5 orang suka minum Susu dan minum Teh serta 3 orang tidak suka keduanya, maka tentukan banyaknya siswa kelas 7.4 tersebut?

Jawaban siswa: 


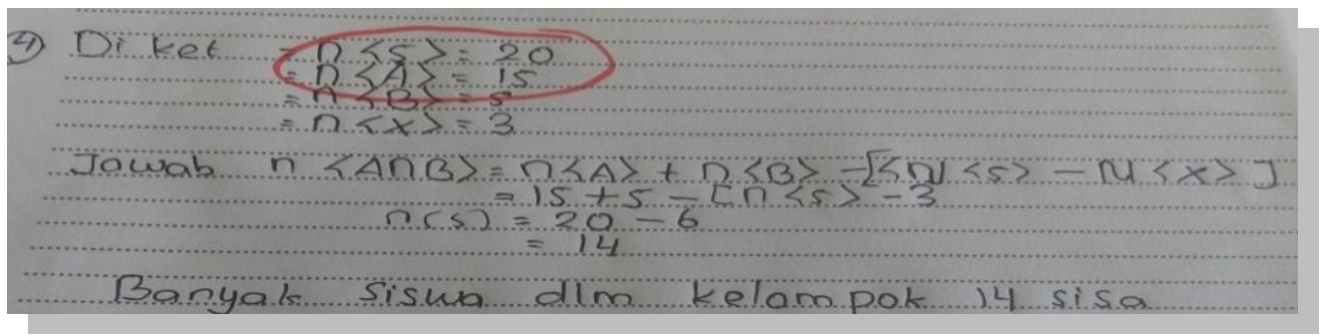

Gambar. 2 Pekerjaan S- 19

Gambar.2 Pekerjaan S-19 menunjukkan bahwa siswa melakukan kesalahan dalam memahami masalah yang disajikan kedalam kalimat matematika.Siswa belum bisa menulis kembali informasi yang benar dalam bentuk model matematika. Pertanyaan yang seharusnya dijawab tetapi dituliskannya diketahui. Hal ini sesuai dengan peneltian yang dilakukan oleh Shofia Hidayat (2016) kesalahan yang paling sedikit dilakukan siswa yaitu memahami soal sebesar $5 \%$.

b. Kesalahan Menyusun Masalah

Berdasarkan hasil perhitungan data pada grafik-1, persentase kesalahan proses penyelesaian sebesar $32,67 \%$. Total proses penyelesaian yang dilakukan siswa adalah 49. Berikut contoh dokumentasi kesalahan menyusun rencana dapat dilihat dari jawaban siswa pada soal no. 3 sebagai berikut:

Dalam suatu kelas yang terdiri atas 40 siswa dilakukan pendataan olahraga yang disukai, terdapat 18 siswa menyukai Atletik, 15 siswa menyukai senam, dan ada 6 siswa yang tidak gemar kedua-duanya. banyaknya siswa yang hanya menyukai Atletik saja adalah ........

Jawaban siswa:

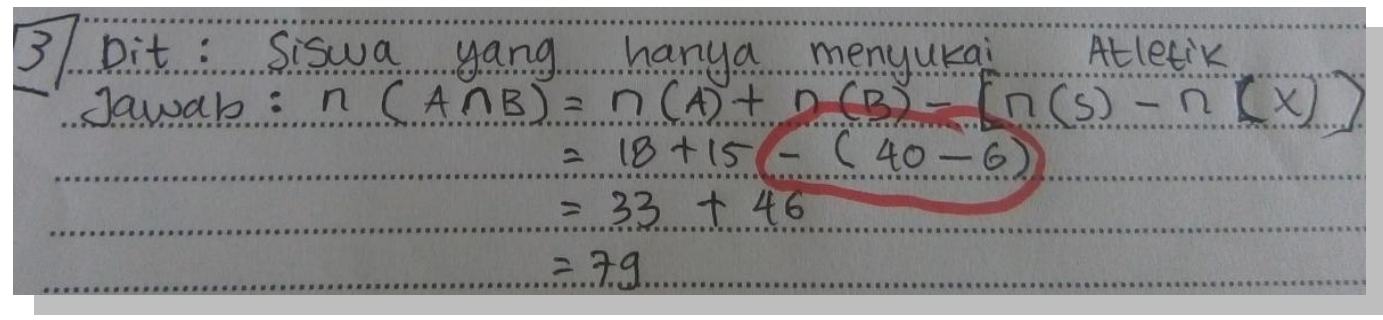

Gambar.3 Pekerjaan S-2

Pekerjaan S-2 menunjukkan siswa sebenarnya sudah mampu memahami soal dan sudah benar tetapi melakukan tahap menyusun rencana salah ( salah perhitungan). Pada Gambar.3 siswa tidak menuliskan kembali informasi yang diketahui sehingga tahapan 
menulis rencana selanjutnya salah. Hal ini sejalan dengan penelitian Shofia Hidayat (2016) kesalahan yang masih dilakukan siswa pada saat menyusun rencana masalah sebesar $21,50 \%$.

c. Kesalahan Melaksanaan Rencana

Berdasarkan hasil perhitungan data pada grafik-1, persentase kesalahan penarikan kesimpulan sebesar 40,00\%. Total kesalahan dalam melaksanaan rencana yang dilakukan siswa adalah 60. Pada penelitian ini kesalahan penarik dalam melaksanakan menyelesaikan soal cerita materi himpunan terdapat beberapa indikator yang menunujukan siswa termasuk dalam kesalahan melaksanakan rencana. Berikut ini contoh dokumentasi kesalahan dalam melaksanakan rencana dapat dilihat dari jawaban siswa pada no. 2 sebagai berikut:

Dinas Kesehatan Kabupaten Siak akan meneliti makanan ringan yang dimakan siswa kelas 7 SMPN 1 Mempura. Dari hasil penelitian,tercatat 18 merek makanan mengandung zat pewarna sitensis, 24 merek mengandung menyedap rasa buatan, dan 10 merek mengandung kedua zat tersebut. Jika ada 9 merek yang tidak mengandung keduanya. Tentukan Banyaknya merek makanan ringan yang diteliti oleh Dinas Kesehatan?

Jawaban siswa:

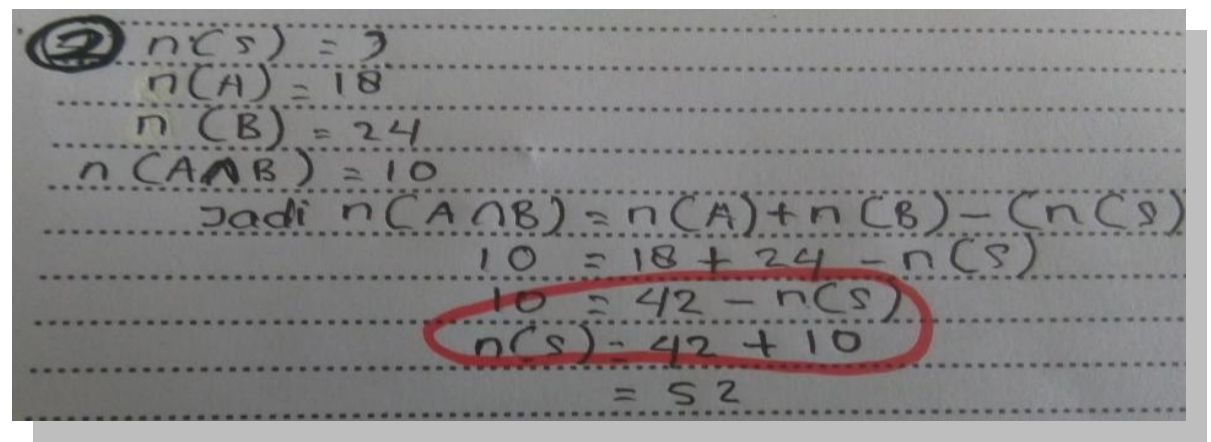

Gambar. 4 Pekerjaan S-21

Pekerjaan S-21 menunjukan bahwa siswa melakukan kesalahan dalam melaksanakan rencana yaitu proses melaksanakan rencana penyelesaian salah.proses perhitungan kurang teliti seharusnya penyelesainnya tidak dijumlahkan $\{n(s)=42+10$ ) \} tetapi yang benar adalah $\mathrm{n}(\mathrm{s})=42-10=32$. 


\section{Soal No. 3}

Dalam suatu kelas yang terdiri atas 40 siswa, diketahui 18 siswa menyukai atletik,15 siswa menyukai senam dan 6 siswa menyukai kedua-keduanya. Tentukan banyak siswa yang hanya menyukai Atletik?

Jawaban siswa:

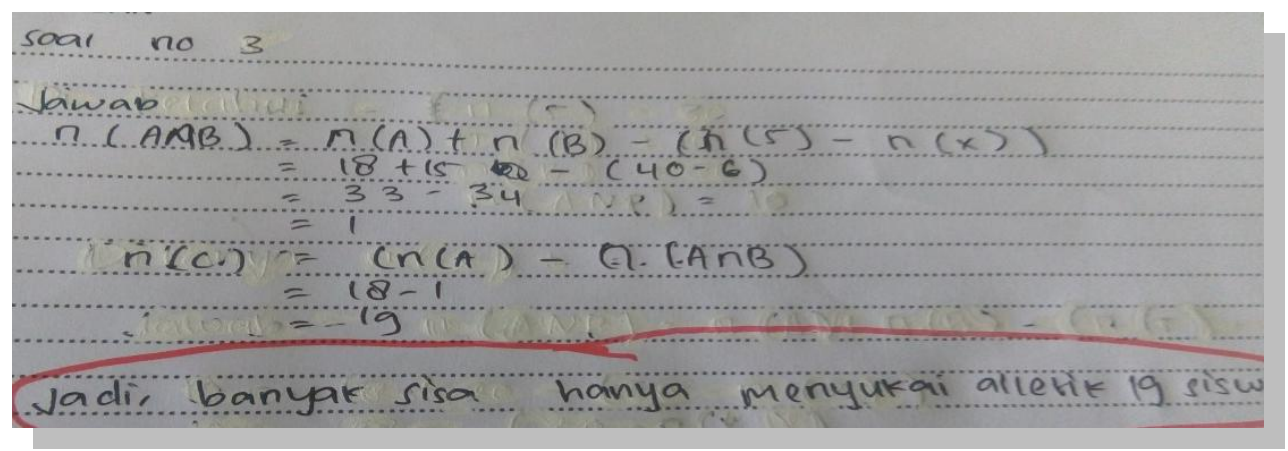

Gambar. 5 Pekerjaan S-15

Pekerjaan S-15 menunjukan bahwa siswa melakukan kesalahan tidak menjawab dari soal. Hal ini karena pada langkah awal sudah salah sehingga siswa tidak dapat menyelesaiakan masalah dalam melaksanakan rencana yang akan diselesaikan. Langkah-langkah proses penyelesaian salah menuliskan informasi yang sudah diketahui. Hal ini sejalan dengan penelitian Shofia Hidayat (2016) kesalahan yang masih dilakukan siswa pada saat melaksanakan rencana masalah sebesar 22,88 \%. Kesalahan dalam mengecek kembali jawaban.

Berdasarkan perhitungan data pada grafik -1 kesalahan siswa dalam mengecek kembali jawaban sebesar $20 \%$, meskipun masih dalam kualifikasi rendah tetapi kesalahan ini masih dilakukan siswa.

Perhatikan dokumentasi pada gambar.6. Kesalahan yang dilakukan siswa dalam mengecek kembali jawaban yang telah diselesaikannya pada soal no. 5 sebagai berikut :

Dalam pendataan terhadap 40 Siswa kelas 7.1 SMPN 1 Mempura, Diketahui 19 siswa yang menyukai pelajaran Matematika dan 20 siswa menyukai pelajaran Bahasa Inggris. Sementara banyaknya siswa yang menyukai pelajaran Matematika dan Bahasa Inggris adalah 10. Tentukan banyak siswa yang tidak menyukai pelajaran Matematika dan Bahasa Inggris? 
Jawaban Siswa:

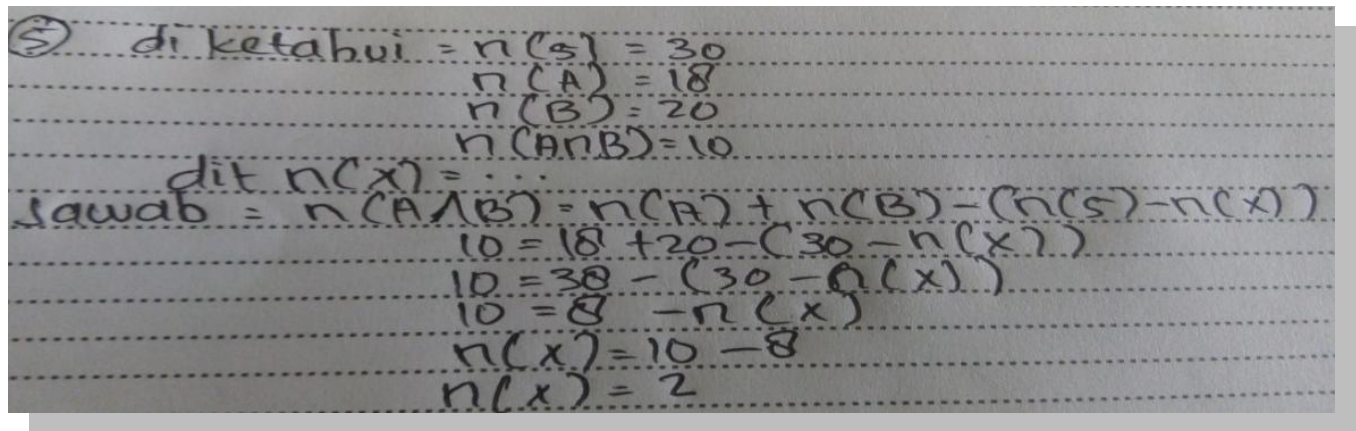

Gambar. 6 Penggalan Pekerjaan S-24

Pekerjaan S-24 menunjukan bahwa siswa melakukan kesalahan tidak menuliskan kesimpulan dari solusi yang diperoleh. Hal ini dilakukan siswa karena siswa tidak mengecek lagi jawabannya dikarenakan kehabisan waktu dan ada juga siswa tidak mau mengecek lagi soal yang telah dibuatnya karena malas. Hal ini sejalan dengan penelitian Shofia Hidayat (2016) kesalahan yang dilakukan siswa pada saat memeriksa jawaban kembali sebesar 18,00\%.

\section{KESIMPULAN}

Tingkat kesalahan siswa dalam menyelesaian soal cerita masih tinggi. Jenis kesalahan yang dilakukan siswa dalam menyelesaikan soal cerita materi himpunan pada saat mengerjakan soal tes yang diberikan guru yaitu kesalahan pemahaman masalah sebesar $5,33 \%$, kesalahan menyusun rencana sebesar 32,67\%, kesalahan melaksanaakan rencana $40 \%$ dan kesalahan mengecek kembali jawaban sebesar 22\%,. Persentase kesalahan yang paling banyak dilakukan oleh siswa adalah kesalahan pada waktu langkah melaksanakan rencana masalah sebesar $40 \%$.

\section{UCAPAN TERIMA KASIH}

Penulis menyampaikan ucapan terima kasih yang setinggi-tingginya kepada:

1. Ibu Yenita Roza, Ph.D dan Dr. Maimunah,M.Si. Selaku dosen pengampu mata kuliah Publikasi Ilmiah yang selalu mengarahkan penulis sehingga dapat menyelesaikan penulisan artikel ini

2. Ibu Winda Harniati, M.Pd selaku Kepala SMPN 1 Mempura dan Siswa kelas 7.4 yang sudah membantu dalam penelitian ini.

3. Suami dan anak tercinta yang selalu memotivasi untuk menyelesaikan artikel ini. 
4. Semua pihak yang telah ikut membantu penulis baik secara langsung maupun tidak langsung dalam proses penyempurnaan penulisan artikel ini.

\section{DAFTAR PUSTAKA}

Hidayah, Shofia (2016). Analisis Kesalahan siswa Dalam Menyelesaikan Soal Cerita SPLDV Berdasarkan Langkah Penyelesian Polya. Prosiding Seminar Nasional Pendidikan Matematika. Universitas kanuruan Malang. Volume 1 tahun 2016

Marlina, L (2013).Panerapan Langkah Polya dalam Menyelesaian Soal Cerita Keliling dan Luas Persegi Panjang. Jurnal Pendidikan Matematika Tadulako vol 1

Rafika dkk (2017). Penerapan Langkah Polya untuk meningkatkan Hasil Belajar siswa dalam menyelesaian soal cerita Sisem Persamaan Linier Dua Variabel Di kelas VIII SMPN 14 Palu. Jurnal Pendidikan Matematika Tadulako vol 5 no. 1 September 2017

Rochmad. 2011. Skema Kognitif Pemecahan Masalah. Semarang: Universitas Negeri Semarang

Muhammad Khadani Sulis,2018, Analisis kesalahan siswa dalam menyelesaian soal cerita PLSV Berdasarkan Teory Polya pada siswa kelas VII SMPN Muhamadiyah 7 Surakarta Tahun 2017/2018. Jurnal Pendidikan Matematika ums.vol 12 tahun 2016

Manibuy, R., Dkk. (2014). Analisis Kesalahan Siswa Dalam Menyelesaikan Soal persamaan Kuadrat Berdasarkan Taksonomi Solopada Kelas X Sma Negeri 1 Plus Di Kabupaten Nabire - Papua. Jurnal Elektronik Pembelajaran Matematika .Issn: 2339-1685 Vol.2, No.9, Hal 933-945. November 2014

T. Khairudin,2017, Analisis strategi pemecahan masalah matematika siswa kelas VII Mts Aceh Besar, 